\title{
MODEL OF LEARNING FOREIGN STUDENTS IN HIGHER MEDICAL INSTITUTIONS: ANALYSIS OF “KROK” EXAMINATION RESULTS
}

\author{
Тернопільський національний медичний університет \\ імені I. Я. Горбачевського МОЗ Украӥни

\section{МОДЕЛЬ НАВЧАННЯ СТУДЕНТІВ-ІНОЗЕМЦІВ У МЕДИЧНИХ ЗАКЛАДАХ ВИЩОЇ ОСВІТИ: АНАЛІЗ РЕЗУЛЬТАТІВ ІСПИТУ«КРОК»}

\begin{abstract}
The article deals with the peculiarities of the content of foreign students education at the universities of Ukraine. The analysis of modern higher medical education stages and the organization of educational process as a whole was made. The comparative characteristic of the foreign students progress based on the results of the licensed test exam "KROK" within certain specialties and the process of adaptation of foreign students to living and studying conditions in Ukraine was noted.
\end{abstract}

Key words: foreign medical students; educational process; professional training; licensed integrated examination.

Анотація. У статті розглянуто особливості змісту освіти іноземних громадян у закладах вищої освіти України, здійснено аналіз етапності сучасної вищої медичної освіти, та організації навчального процесу в цілому. Проведено порівняльну характеристику успішності іноземних студентів за результатами ліцензійного тестового іспиту «Крок» у межах визначених спеціальностей, а також відмічено процес адаптації іноземних студентів до умов проживання і навчання в Україні.

Ключові слова: іноземні студенти-медики; навчальний процес; професійна підготовка; ліцензійний інтегрований іспит.

Introduction. Medical education in Ukraine is an integral part of the national education and health system. It is considered to be one of the best in the world annually attracting thousands of foreign students to the educational process. Graduates of Ukrainian medical universities are highly valued for their fundamental knowledge and excellent practical skills. According to the latest data, our country's educational potential has allowed us to enter the top ten countries in the field of international education, as evidenced by the current demand for higher education in Ukraine by citizens of other countries.

According to the Bologna Process Ukraine reformed its educational system thus adapting it to the European Union standards. Nowadays training for healthcare professionals is taking place in higher medical and pharmaceutical educational institutions of I-IV accreditation levels. Among them there are medical colleges, medical schools and their units, nursing institutes, medical universities, the National

(c) N. I. Hantimurova
University of Pharmacy and academies of postgraduate education. It is worth noting that nowadays the diplomas awarded by Ukrainian educational institutions are widely recognized internationally, and the level of professional training of graduates is highly appreciated by foreign employers.

At present medical education is on the verge of changes that should be able to combine good traditions and achievements of local professional schools and best teaching experience of European universities. These are the fundamentals of building modern educational process registered in the National Strategy of Education Development in Ukraine, where one of the goals is to "improve the quality and competitiveness of education in the new economic and socio-cultural conditions and accelerate integration of Ukraine into international educational space". However, training should promote a harmonious development of the individual, be not only professional but also educational, promote cultural and spiritual education of future specialists. Education is the "the process of transfer and active 


\section{Materials of International Scientific and Practical Conference \\ "PROFESSIONAL AND COMMUNICATION CULTURE OF THE FUTURE DOCTOR: LINGUISTIC, PEDAGOGICAL AND PHILOSOPHICAL ASPECTS”}

assimilation of knowledge, skills, and ways of cognitive activity which are necessary for the continuing education of people. The learning process is twosided and includes teaching - as a teacher's activity (knowledge transfer and management of independent students work) and learning - as students' activities in order to master the system of knowledge, skills and abilities". The modern teacher must develop interactive model where the listener becomes an active participant of the educational process, proposes and performs tasks, sets and achieves learning goals. Therefore, interactive learning technologies in the pedagogical process of medical university is relevant and essential, but this objective characteristic, such as the age of students and interns makes its adjustments in the process of educational material assimilation.

The peculiarities of the content of foreign students education were studied by I. Kushnir, L. Artemenko, V. Bakumenko, M. Yevtukh and others. The main component of foreign students' study in medical universities of Ukraine is the use of innovative technologies (L. Bulat, O. Lysunets, N. Didyk and others), implementation of communicative approach in the system of foreign students' training (L. Herbert, O. Leontieva, O. Smolkina and others) and application of conceptual provisions for the development of education in Ukraine and its entry into the world educational space (V. Sagarda, L. Puhovska, O. Gluzman and others).

The aim - to make the brief analysis of medical education system in the universities of Ukraine and do a comparative characteristic of the foreign students progress based on the results of the licensed test exam "KROK” within certain specialties.

Theoretical framework. The structure of medical education of Ukraine is based on the systems of education of world's leading countries in accordance with the recommendations of the EU, UNESCO, UN and other international organizations. Being an integral part of the Ukrainian educational system, higher medical education in Ukraine is regulated by the Law “About Higher Education”, concept “About Specialization (internship) and "About Medical Residency”. Four-level system of education provides qualitative learning with further assignment of such qualification levels as Junior Specialist, Bachelor, Specialist and Master.

Modern higher education in Ukraine has two stages undergraduate and postgraduate. Undergraduate education is obtained at the following levels: according to the training program "General Medicine”, "Medicine”,
"Nursing”, "Dentistry”, "Pharmacy” and others. The number of distance-learning foreign nursing students continues to grow. So, at I. Horbachevsky Ternopil National Medical University in the year 2016 as of October 31, the number of distance-learning nursing students was 241. In 2017 there studied 249 students, in 2018 - 266 students and in 2019 - 323 foreign students. In Ukraine, as in the most countries, obtaining diploma of doctor and pharmacist does not allow to make an independent practice. Continuing education takes place at the postgraduate compulsory level - internship (1-3 years), after which they are awarded the qualification of doctor or pharmaceutist. Graduates who were enrolled in postgraduate study at higher medical educational institution and research institutes in the specialties not from the field of Medicine and Pharmacy are exempted from passing the internship. Internship can be intramural and extramural, at the departments of higher medical educational institutions of IV level of accreditation and postgraduate education and training [3]. The next stage is a clinical residency, which is not an obligatory form of advanced training for Ukrainian citizens, so entry is competitive. Duration of study is two years. Foreign students do not study internships, but obtain postgraduate training in clinical residency in Ukraine, according to the permission of the Ministry of Health, or abroad. For foreign citizens it lasts for 2-3 years and may be extended for another $1-2$ years [1].

Teaching of foreign students requires creation of comfortable conditions for their adaptation and further education. Adaptation to study at Ukrainian universities is defined as the process of actively adapting students to living conditions of another country, its traditions, norms of social behavior, new social environment; educational environment, which includes new attitude to the profession, educational norms, assessments, methods and techniques of independent work; educational staff, its customs and traditions; new living conditions in the student hostel, new samples of student culture, forms of leisure time usage; assimilation and recognition of personality values, communicative norms and requirements of the new social environment.

At the universities there are separate structural units which are responsible for coordinating the educational process, solving different questions concerning registration of foreigners. In I. Horbachevsky Ternopil National Medical University such a structural unit is Dean's Office of Foreign Student's Faculty. It consists of admission commission the task of which is to select 
and enroll foreigners to certain faculties according to the normative-legal documents of the relevant ministries, which govern this process, immigration department and department which is responsible for educational process.

In order to improve the training conditions and qualifications of future physicians, proper organization of the educational process plays an important role. This is the key to attracting an increasing number of foreigners to Ukraine. For example, at I. Horbachevsky Ternopil National Medical University the Foreign Students Faculty was formed. It consists of Preparatory Faculty, Nursing Institute and 5 departments: Internal Medicine No. 2, Surgery No. 2, Pediatric No. 2, Obstetrics and Gynecology No. 2, Clinical Immunology, Allergology and General Patient Care. At the departments of Foreign Student's Faculty there are highly qualified and experienced teachers who have high levels of proficiency in English, which are confirmed by FCE, TOEFL, IELTS certificates and they usually have international internship. This has improved the quality of foreign citizens training.

The achievement of the learning objectives is ensured by the selection of educational material and didactic processes that contribute to its transfer into the knowledge, skills and personal qualities of the specialist, which are recorded in the relevant curriculum documentation, the basis of which are educational standards, qualifications and professiogram of the specialist.

In order to implement the relevant educational and professional program in higher educational institutions a regulatory document which is called the curriculum is being developed. It indicates the list and quantity of normative and selective educational disciplines, the sequence of their study, specific methods of education (lectures, laboratory, practical, seminar, individual classes, consultations, educational and manufacturing practices) and its volume, schedule of the educational process, forms and means of conducting current and final control. The curriculum also indicates the time allotted for independent work.

In higher medical institutions the learning process is structured. So, in particular, in junior courses foreign students mainly study the humanitarian and socioeconomic disciplines, such as: philosophy, history of Ukraine, basics of economic theories, basics of psychology and pedagogy, etc., also natural science (fundamental) training, such as: Latin language and medical terminology, history of medicine, medical biology, medical chemistry, biological and bioorganic chemis- try, human anatomy, histology, cytology and embryology, physiology, microbiology, etc. Senior students study disciplines of professional training, such as: obstetrics and gynecology, otorhinolaryngology, ophthalmology, general surgery, propaedeutics of internal medicine, oncology, pathomorphology, pathophysiology, oncology, urology, etc. In addition, the curriculum of medical universities of Ukraine include elective courses that focus on the individual preferences of the student. So, for example, at I. Horbachevsky Ternopil National Medical University, such elective courses for international students are: science of law, premedical aid in extreme situations, the Ukrainian language, molecular biology, clinical biochemistry, actual diagnostic issues, actual issues in hematology and transfusiology, clinical laboratory diagnostics in internal medicine, medical rehabilitation and others [5].

In order to establish the level of students, graduates and interns professional competence to the minimum required level in accordance with the requirements of the State Higher Education Standards, a licensed integrated examination "KROK” is conducted. It includes one, two or three separate test exams depending on the level of qualification. The content of test exams of the licensed integrated examination is approved annually by the Ministry of Health of Ukraine and should correspond to educational and professional programs that are approved by the Ministry of Education of Ukraine.

Future Specialist and Master degree professionals (doctors, dentists, pharmacists, psychologists etc.) adherently pass three examinations - "KROK 1", "KROK 2" and "KROK 3". Future Junior specialists pass one exam - "KROK M". Future Bachelor's degree professionals adherently pass two examinations "KROK M" and "KROK B".

Foreign medical students showed high results in passing the licensed integrated exam in recent years. In 2017 according to the Testing Center of the Ministry of Health of Ukraine 3189 international students were writing "KROK 1 General Medicine”. 540 students didn't pass the exam. The results of the licensed exam for foreign students in 2018 were higher. 3358 foreign students were writing exam. Among them 528 students didn't pass (Fig. 1, Fig. 2).

Foreign medical students studying at I. Horbachevsky Ternopil National Medical University show high results during passing the licensed integrated exam "KROK” (Fig. 3).

In order to test the acquisition of clinical skill and competence of medical students an Objective Structured 


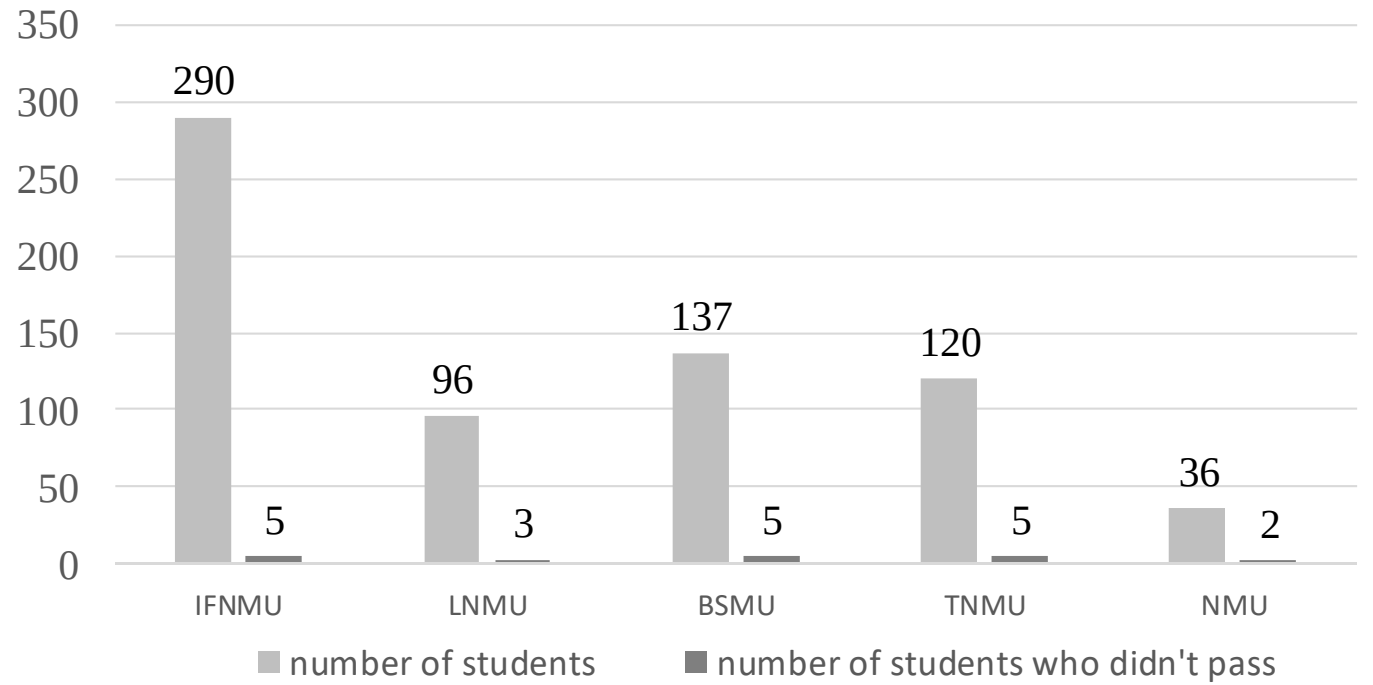

Fig. 1. Number of students who did not pass “KROK-2. Medicine” in 2018 at medical universities of Ukraine.

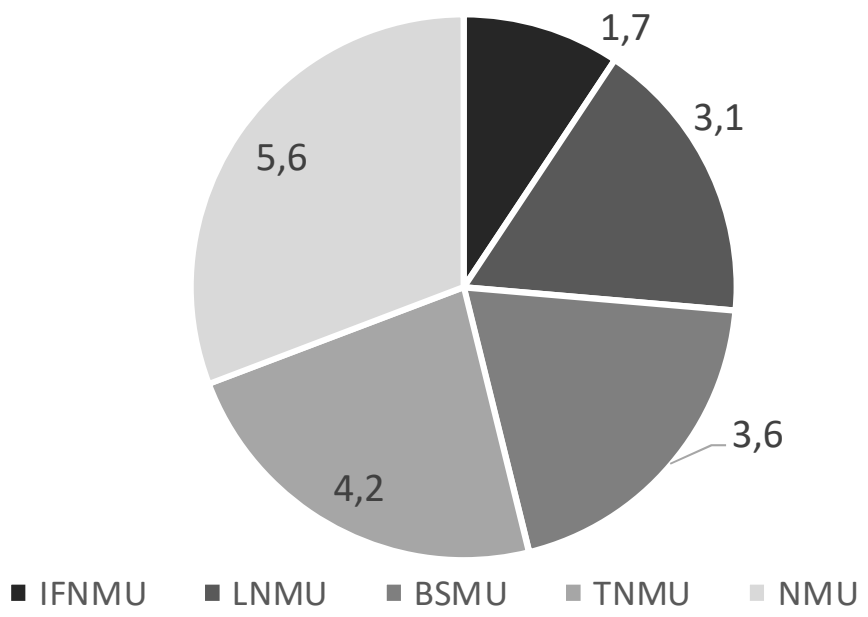

Fig. 2. Percentage of students who didn't pass “KROK-2. Medicine” in 2018 at medical universities of Ukraine.

Clinical Examination (OSCE) was organized. One of the first medical institutions of higher education in Ukraine, which established OSCE in order to test students' practical skills was I. Horbachevsky Ternopil National Medical University. The exam takes place in rooms that correspond to those available in hospitals. Real medical instruments and consumables are used. As a patient may be a specially trained person - a standardized patient or a mannikin, model or phantom that represents the whole body or part of it. The need to evaluate students' practical skills appears with the beginning of clinical disciplines study. This exam in basic clinical disciplines is taken by students of $3^{\text {rd }}, 4^{\text {th }}, 5^{\text {th }}$ years of study in the specialty "Medicine" - "General Medicine" and $3^{\text {rd }}, 4^{\text {th }}$ years of study in the specialty "Dentistry". This form of knowledge and skills control makes it possible to evaluate not only theoretical knowledge and practical skills, but also the ability to apply them comprehensively in real-life situations, and provides a high level of objectivity in assessing competencies through the implementation of the basic exam principles.

An important condition for the approval of students as specialists of high qualification level is participation in scientific work, various scientific and practical meetings and conferences. Foreign students are active participants in the programs and activities of the Student Scientific Society of the University. They also created their own societies, including the Ternopil Branch of European Association of Medical Students (EMSA) where more than 50 people from different nationalities are members and Association of Medical Students. The purpose of these societies is to conduct scientific and practical research at various departments 


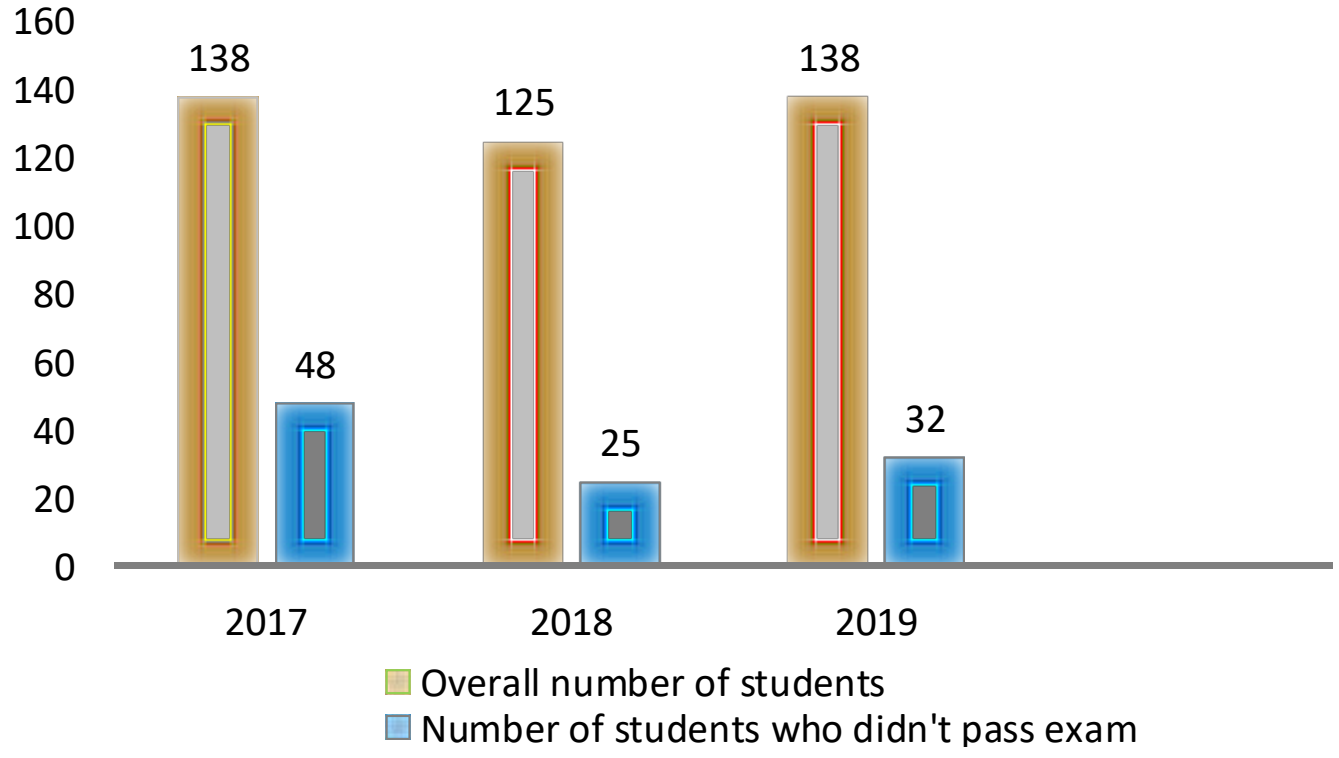

Fig. 3. The number of foreign medical students who didn't pass "KROK 1" on the first attempt.

under the guidance of the university's teachers. Many students are members of the International Christian Medical Association (ICMA). They participate in annual conferences, where workshops are conducted by well-known specialists from various fields of medicine from the USA, the Netherlands, Great Britain, Nigeria, and Ghana.

Conclusions and Prospects for Research. So, after a brief analysis of the medical education system in the universities of Ukraine on the example of I. Horba- chevsky Ternopil National Medical University we can make conclusion on the approval of national medical education system in the common European educational space, based on the introduction of the latest teaching methods and assessment of knowledge and skills of foreign students and the growth of quality indicators progress according to the results of the licensed test exam "KROK" and OSCE, as well as a clear tendency to an annual increase of the number of foreign students as applicants for medical education in Ukraine.

\section{List of literature}

1. Моніторинг якості медичної освіти / під заг. ред. I. Є. Булах. - К. : Центр тестування при МОЗ України, 2005. - 143 с.

2. Навчальний план підготовки фахівців освітньо-кваліфікаційного рівня «Спеціаліст» кваліфікації «Лікар» у вищих навчальних закладах III-IV рівнів акредитації України. Спеціальність 7.110101 «Лікувальна справа». Погоджено МОН України 17.06.2002 р., затверджено МОЗ України 18.06.2002 р. - Тернопіль : Укрмедкнига, 2003. - 19 с.

3. Про затвердження Положення про клінічну ординатуру : наказ МОЗ України від 29.01.1998 р. № 12 [Електронний ресурс]. - Режим доступу : http://zakon3.rada. gov.ua/laws/show/z0106-98.

\section{References}

1. Bulakh, I.Ye. (Ed.). (2005). Monitorynh yakosti medychnoi osvity [Monitoring of medical education quality]. Kyiv: Test center at the Ministry of Health of Ukraine [in Ukrainian].

4. Про затвердження Положення про спеціалізацію (інтернатуру) випускників вищих медичних і фармацевтичних закладів освіти III-IV рівня акредитації медичних факультетів університетів : наказ МОЗ України від 19.09.1996 р. № 291 із змінами, внесеними згідно 3 наказом МОЗ від 07.02.2001p. № 47 (z0138-01) [Електронний ресурс]. - Режим доступу : http://zakon5.rada. gov.ua/laws/show/z0696-96.

5. Робочий навчальний план спеціальності 222 «Медицина» / Тернопільський національний медичний університет імені І. Я. Горбачевського МОЗ України. Тернопіль, 2019. - 7 с.

2. Navchalnyi plan pidhotovky fakhivtsiv osvitniokvalifikatsiynoho rivnia "Spetsialist” kvalifikatsii "Likar" $u$ vyshchykh navchalnykh zakladakh III-IV rivniv akredytatsii Ukrainy. Spetsialnist 7.110101 “Likuvalna sprava” [Cur- 


\section{Materials of International Scientific and Practical Conference \\ "PROFESSIONAL AND COMMUNICATION CULTURE OF THE FUTURE DOCTOR: LINGUISTIC, PEDAGOGICAL AND PHILOSOPHICAL ASPECTS”}

riculum for specialists preparation of educational and qualification level "Specialist" of qualification "Doctor" in Ukrainian higher educational institutions of III-IV levels of accreditation]. Specialty 7.110101 “General Medicine”. Agreed by Ministry of Education of Ukraine 17.06.2002, approved by Ministry of Health of Ukraine 18.06.2002. Ternopil: Ukrmedknyha [in Ukrainian].

3. Nakaz MOZ Ukrainy "Pro zatverdzennia polozhennia pro klinichnu ordynaturu” [The order of Ministry of Health of Ukraine "About confirmation of clinical residency establishment”] No. 12 of 29.01.1998. Retrieved from: http://zakon3.rada.gov.ua/laws/show/z0106-98 [in Ukrainian].

4. Nakaz MOZ Ukrainy "Pro zatverdzennia polozhennia pro spetsializatsiiu (internaturu) vypusknykiv vyshchyh medychnyh i farmatsevtychnyh zakladiv osvity III-IV rivnia akredytatsii medychnyh fakultetiv universytetiv" [The order of the Ministry of Health of Ukraine "About confirmation of specialization (internship) of higher medical and pharmaceutical educational establishments of IIIIV level of accreditation graduates of medical faculties of universities"]. No.291 of 19.09.1996 with changes according to the Ministry of Health Order No.: 47 (z0138-01) of 07.02.2001p. Retrieved from: http://zakon5.rada.gov.ua/ laws/show/z0696-96 [in Ukrainian].

5. (2019). Robochyi navchalnyi plan spetsialnosti 222 "Medytsyna" [Curriculum of specialty 222 "Medicine"]. I. Horbachevsky Ternopil National Medical University of Ministry of Health of Ukraine of 25.05.2019. Ternopil [in Ukrainian].

E-mail address for correspondence: hantimurova_n@tdmu.edu.ua 